\title{
Management of Ruptured Hepatocellular Adenoma
}

\author{
Volkert A.L. Huurman Alexander F.M. Schaapherder \\ Department of Surgery, Leiden University Medical Center, Leiden, The Netherlands
}

\section{Key Words}

Hepatocellular adenoma • Non-ruptured hepatocellular adenoma, management $\cdot$ Radiofrequency ablation • Ruptured hepatocellular adenoma, management · Transarterial embolization

\begin{abstract}
Hepatocellular adenoma (HA) is an increasingly prevalent benign liver tumor that is strongly associated with use of oral contraceptive medication. The diagnosis is often made after abdominal imaging in female patients with sudden abdominal pain, with or without signs of hemorrhage. Especially larger adenomas are of potential hazard to patients, because of the increased likelihood of rupture or malignant degeneration. Standard treatment of larger adenomas has since long consisted in surgical resection, both for non-ruptured and for ruptured tumors. Although resection is still considered the gold standard, recent reports have advocated initial conservative management. Recently, newer and less invasive methods using selective transarterial embolization have been described that can successfully stop bleeding and even lead to tumor regression. This review addresses different treatment options and recent advances regarding this relatively new condition, focusing mainly on treatment of bleeding and ruptured tumors in an acute setting. A possible algorithm for optimal treatment is presented.
\end{abstract}

Copyright $\odot 2010$ S. Karger AG, Base

\section{KARGER}

Fax +41613061234 E-Mail karger@karger.ch www.karger.com

\section{Introduction}

Liver or hepatocellular adenoma (HA) is a rare benign liver tumor that occurs mostly in women of reproductive age. First noted in the 1860s, its incidence has risen strongly in the last decades. This rise is mostly due to the strongly increased use of hormonal oral contraceptives, to which this condition is strongly related [1]. The current estimated incidence of HA is 1-3 per 100,000 per year [2]. Its pathologic features are characterized by a benign proliferation of hepatocytes of unknown origin that may be related to hormone changes. Recent studies have revealed an association between HA and mutations in the hepatocyte nuclear factor-1 $\alpha$ (HNF1A) gene [3]. Malignant transformation of HA is rare and associated with $\beta$ catenin mutations that are also found in hepatocellular carcinoma $[4,5]$. The presence of $>10 \mathrm{HAs}$ is termed hepatic adenomatosis, a condition that is associated with the presence of maturity-onset diabetes of the young (MODY) (also through HNF1A gene alterations) [6]. No clear relation of hepatic adenomatosis to contraceptive use has been proven.

\section{Management of Non-Ruptured HA}

The diagnosis of HA without rupture is most often made incidentally when abdominal imaging is performed for other reasons. Only a small percentage of patients pre- 
senting with symptoms of acute abdominal pain or elevated liver enzymes are diagnosed with non-ruptured HA. Suspected HA on ultrasound should first be confirmed by contrast-enhanced CT or MRI [7]. Historically, tumors sized $<5 \mathrm{~cm}$ are initially treated conservatively [8]. Discontinuation of oral contraceptives has been suggested to lead to regression of tumor size or even disappearance of smaller HA [8-12], as have dietary measures in patients with glycogenosis $[13,14]$.

A recent multicentric report of the largest patient group described thus far $(\mathrm{n}=124)$ identified contraceptive use and tumor size $>7 \mathrm{~cm}$ as risk factors for rupture [15]. No significant risk factors for malignant transformation were identified due to the low incidence of malignancy (4\%). Noticing that tumors tend to be estimated larger after rupture, the authors advocate surgical resection of non-ruptured tumors $>4 \mathrm{~cm}$. A monocentric study on 122 patients found an increased risk of complications for HAs $>5 \mathrm{~cm}$, limiting resection only to these cases [16]. In contrast, another retrospective report on 41 patients advocates resection of all anatomically reachable lesions regardless of size [17], based on the high incidence of hemorrhage (30\%) and malignancy (5\%). Surgery can be performed either open or laparoscopically, dependent on the localization and size of the tumor as well as local experience. In a report form the Rotterdam group, a caseoriented approach is followed that bases the decision to perform surgery on the effect of initial conservative measures [18].

Newer, less invasive ways to treat non-ruptured HA include radiofrequency ablation (RFA) and selective transarterial embolization (TAE). In several cases, these modalities have shown to be able to selectively put the adenoma into regression $[15,19,20]$.

We advocate initial conservative treatment of nonruptured HA, with a possible role for TAE in selected cases. Large $(>5 \mathrm{~cm})$ or easily accessible HAs, that do not decrease in size upon conservative management, may be resected in an elective setting. Optimal treatment should first be discussed in a multidisciplinary meeting between liver surgeon, hepatologist and radiologist.

\section{Management of Ruptured HA}

Many HAs are first diagnosed in symptomatic patients presenting with acute abdominal pain, hemodynamic instability or other signs of rupture (in $58-65 \%$ of patients who use oral contraceptives, in $25 \%$ of those who do not) $[15,21]$. Much debate still exists regarding the op-

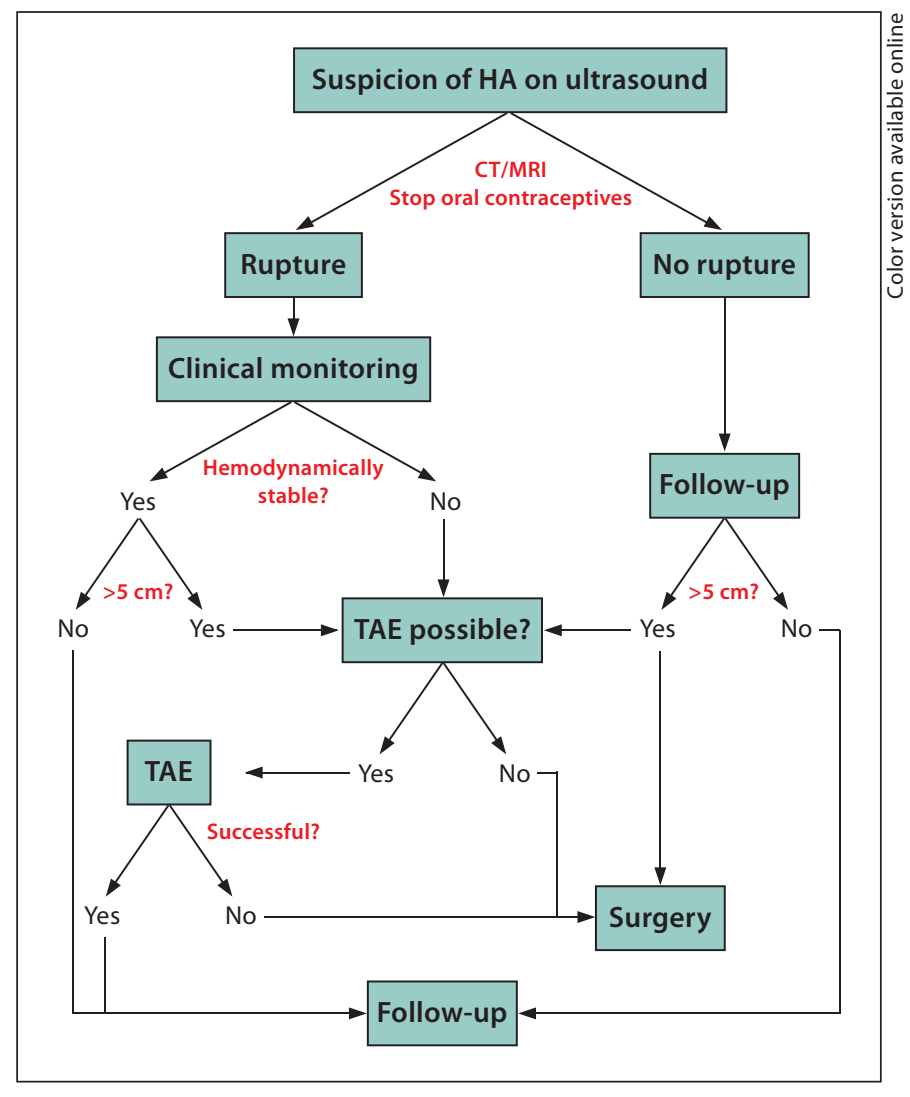

Fig. 1. Possible algorithm for management of patients with HA.

timal treatment in this acute situation. A review of the recent literature (since 1999) incorporating case series ( $n>10)$ and observational studies on this subject is included in table 1. Different treatments are advocated with varying results. In our view, treatment should be tailormade for each individual patient, based on clinical parameters and available expertise. A possible decision flow chart is shown in figure 1.

First, after prompt resuscitation has been initiated, it is important to identify the extent and hemodynamic consequences of the ruptured HA. Rupture may have lead to intrahepatic or intraperitoneal bleeding with or without signs of hypovolemic shock. Appropriate imaging studies should be performed. In case of hypovolemia and acute abdominal pain, emergency ultrasound will most often be the first diagnostic tool, upon which the diagnosis of ruptured HA may be suspected. At that point, we recommend the routine use of contrast-enhanced CT to further identify the exact anatomy and diagnosis. A single HA may be present but also multiple HAs with localizations in differ- 
Table 1. Recent literature case series on treatment of ruptured HA. A PubMed search was performed with key words 'ruptured hepatocellular adenoma' and 'treatment' in articles published in 1999 or later. Only case series describing more than 10 patients were included in this table.

\begin{tabular}{|c|c|c|c|c|c|c|c|}
\hline $\begin{array}{l}\text { Reference } \\
\text { (first author) }\end{array}$ & Year & $\begin{array}{l}\text { Patients } \\
\mathrm{n}\end{array}$ & $\begin{array}{l}\text { Ruptured adenomas } \\
\mathrm{n}(\% \text { of total })\end{array}$ & Treatment & $\begin{array}{l}\text { Complica- } \\
\text { tions, } \%\end{array}$ & $\begin{array}{l}\text { Mortality } \\
\%\end{array}$ & Advice on treatment \\
\hline $\begin{array}{l}\text { Terkivatan } \\
{[8]}\end{array}$ & 2001 & 12 & $12(100)$ & $\begin{array}{l}\text { Conservative }(4 / 12) \\
\text { Immediate surgery }(3 / 12) \\
\text { Postponed surgery }(5 / 12)\end{array}$ & 25 & 0 & $\begin{array}{l}\text { Stabilization, conservative measures, } \\
\text { surgery only on indication }\end{array}$ \\
\hline $\begin{array}{l}\text { Toso } \\
{[25]}\end{array}$ & 2005 & 25 & $10(40)$ & $\begin{array}{l}\text { Immediate surgery }(0 / 10) \\
\text { Postponed surgery }(10 / 10) \\
\text { (1 preoperative TAE) }\end{array}$ & 20 & 0 & $\begin{array}{l}\text { Stabilization with or without TAE, } \\
\text { postponed surgery }\end{array}$ \\
\hline $\begin{array}{l}\text { Erdogan } \\
{[28]}\end{array}$ & 2006 & 22 & $22(100)$ & $\begin{array}{l}\text { Conservative }(5 / 22) \\
\text { Definitive TAE }(1 / 22) \\
\text { Immediate surgery }(6 / 22) \\
\text { Postponed surgery }(10 / 22)\end{array}$ & 14 & 0 & $\begin{array}{l}\text { Stabilization, surgery only on } \\
\text { indication }\end{array}$ \\
\hline $\begin{array}{l}\text { Van der Windt } \\
{[18]}\end{array}$ & 2006 & 48 & $13(27)$ & $\begin{array}{l}\text { Conservative }(8 / 13) \\
\text { Definitive TAE }(2 / 13) \\
\text { Postponed surgery }(3 / 13) \\
\text { (1 preoperative TAE) }\end{array}$ & 31 & 0 & $\begin{array}{l}\text { Stabilization, conservative measures, } \\
\text { surgery only on indication }\end{array}$ \\
\hline $\begin{array}{l}\text { Stoot } \\
{[20]}\end{array}$ & 2007 & $\begin{array}{l}11(25 \\
\text { adenomas })\end{array}$ & $17(68)$ & $\begin{array}{l}\text { Definitive TAE }(9 / 11) \\
\text { Postponed surgery }(2 / 11) \\
\text { (2 preoperative TAE) }\end{array}$ & 35 & 0 & $\begin{array}{l}\text { Stabilization, TAE, surgery only on } \\
\text { indication }\end{array}$ \\
\hline $\begin{array}{l}\text { Cho } \\
{[17]}\end{array}$ & 2008 & 41 & $12(29)$ & $\begin{array}{l}\text { Immediate surgery }(\mathrm{n}=12) \\
(1 \text { preoperative TAE })\end{array}$ & 9 & 0 & $\begin{array}{l}\text { Stabilization with or without TAE, } \\
\text { immediate surgery }\end{array}$ \\
\hline $\begin{array}{l}\text { Deneve } \\
{[15]}\end{array}$ & 2009 & 129 & $31(25)$ & $\begin{array}{l}\text { Postponed surgery }(\mathrm{n}=31) \\
(5 \text { preoperative TAE, } 1 \\
\text { preoperative RFA) }\end{array}$ & 26 & 0 & $\begin{array}{l}\text { Stabilization with or without } \\
\text { TAE/RFA, postponed surgery }\end{array}$ \\
\hline $\begin{array}{l}\text { Dokmak } \\
{[16]}\end{array}$ & 2009 & 122 & $26(21)$ & $\begin{array}{l}\text { Immediate surgery }(n=6) \\
\text { Postponed surgery }(n=6) \\
(12 \text { preoperative TAE })\end{array}$ & 15 & 0 & $\begin{array}{l}\text { Stabilization with or without TAE, } \\
\text { postponed surgery of HAs }>5 \mathrm{~cm}\end{array}$ \\
\hline
\end{tabular}

ent segments of the liver. The ruptured HA may be located at the liver edge or be fully surrounded by parenchyma. If the patient is hemodynamically unstable despite adequate resuscitation, immediate intervention is required. Gold standard has been to perform emergency laparotomy with gauze packing or partial liver resection to achieve adequate hemostasis. However, this is a major surgical procedure with considerable morbidity and mortality. Laparoscopic resection is also possible in theory, but is technically difficult and may therefore prove unwise in an unstable patient. Liver transplantation as treatment for either ruptured or non-ruptured adenomas has been reported but is rarely indicated $[22,23]$.

Recently, less invasive procedures such as TAE have been developed that may also lead to adequate hemostasis without the need for urgent laparotomy. RFA to selectively destroy HA has only been used in non-ruptured adenomas and its use after hemorrhage may be considered irrelevant [24].
In several studies, mainly performed in different Dutch centers, TAE has been shown to lead to hemodynamic stabilization in selected patients with acceptable morbidity and possible beneficial effect on tumor size [15, 17-21, 25]. An emergency surgical resection with accompanying high morbidity and mortality, and possibly also secondary resection, can be avoided. However, it is important to realize that only a selected patient group in a center with adequate radiological experience can be treated with TAE. In a series from our own center, 10 of 11 patients with ruptured HA were stabilized after a single TAE, while 1 other patient needed three TAEs [20]. No emergency resections were needed and only minor complications were found (an example is shown in figure 2). In all patients, tumor size decreased after followup, with secondary resection being indicated only in a minority of patients.

Occurrence and possible rupture of HA during pregnancy puts forward a surgical dilemma: reluctance to op- 


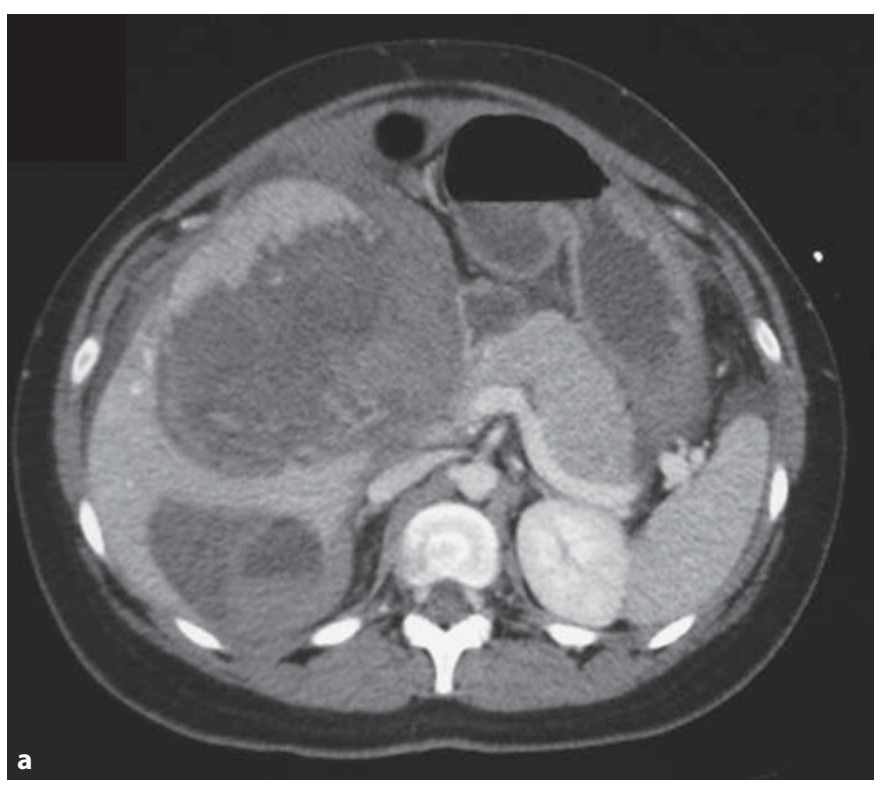

Fig. 2. a Contrast-enhanced CT scan of a patient at presentation with acute-onset abdominal pain, based on two ruptured HAs with signs of recent hemorrhage and hemodynamic instability. The largest tumor measured $10 \mathrm{~cm}$. The patient was stabilized conservatively and immediate selective TAE was performed,

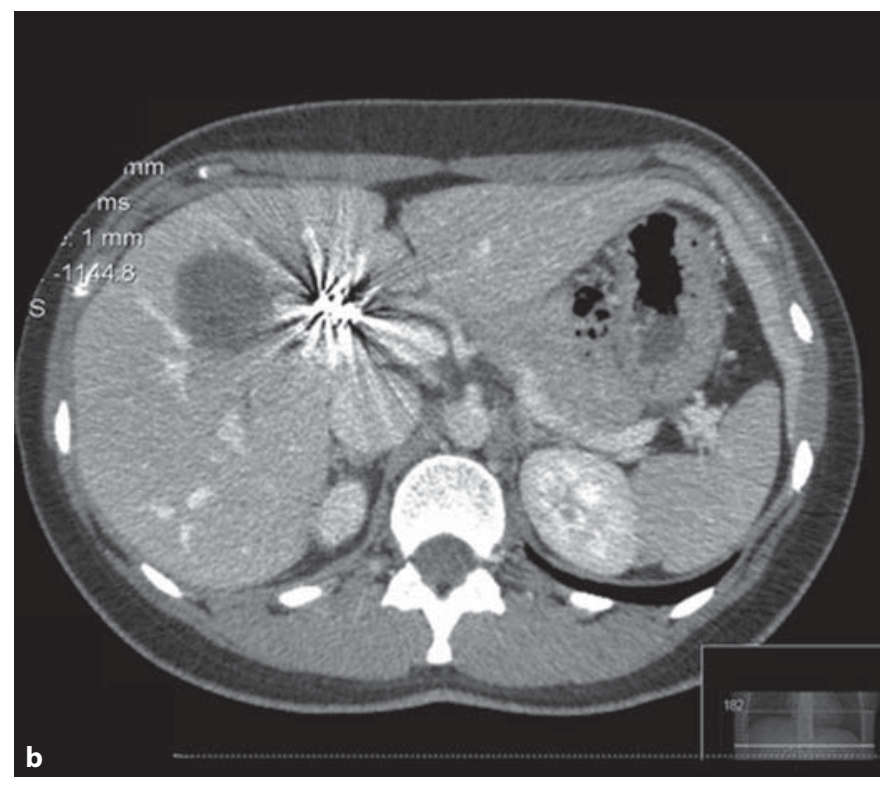

stopping the hemorrhage. b Follow-up contrast-enhanced CT scan 4 years after embolization: the tumor in segment 4 has decreased to a size of $3 \mathrm{~cm}$, whereas the tumor in segment 6 is no longer detectable. erate on a pregnant patient combined with a possible dangerous condition. For these cases, minimally invasive TAE may also be favorable $[26,27]$.

If the patient responds to resuscitation and remains stable, conservative treatment may be appropriate $[8,28]$. Obviously, oral contraceptives should be discontinued. Varying cut-off sizes above which tumors should be secondarily resected have been proposed. Based on the available literature, we would recommend secondary resection of tumors $>5 \mathrm{~cm}$. Conservative measures and selective TAE may lead to tumor regression, causing a large lesion to shrink to $<5 \mathrm{~cm}[20,29]$. In that case, secondary surgery may not be required and regular clinical and radiological follow-up will suffice.

\section{Follow-Up}

As argued above, recent literature has suggested a role for conservative or minimally invasive treatment of both ruptured and non-ruptured HA. Follow-up after initial conservative treatment should include regular patient visits as well as visualization, preferably by contrast-enhanced CT or MRI. During follow-up, the same treatment decision algorithm should be followed as upon di- agnosis. After initial rupture, however, the size of the lesion may be difficult to define [15].

If lesions grow $>5 \mathrm{~cm}$ despite conservative measures or TAE, resection is required because of the increased risk of hemorrhage and malignant transformation. Regular imaging of the liver is also indicated after initial resection because new adenomas may develop or old ones may recur.

No clear advice can be given on the frequency and duration of follow-up. No evidence exists for added value of long-term follow-up to prevent malignant degeneration. In any case, it makes sense to stop follow-up after menopause.

\section{Conclusion}

HAs form an increasing health problem for young women, mainly due to increased oral contraceptive use. Until recently, management was often limited to cessation of hormone use and laparotomy to prevent or stabilize potentially life-threatening rupture, a major event in this otherwise healthy group of patients. The acute presentation of many patients with ruptured HA practically rules out randomized trials to compare different treat- 
ments. Especially in this setting, clinical decision-making based on results from cohort studies seems appropriate. Recent observational studies have suggested a treatment policy optimized for each patient individually, allowing initial conservative treatment. An increasing role is observed for new minimally invasive procedures such as TAE, which may be considered first-line treatment for ruptured HA if sufficient experience is available. The flow chart presented in figure 1 offers an algorithm that provides each patient with the appropriate treatment, avoiding major surgery with associated morbidity and mortality in selected patients.

\section{References}

1 Rooks JB, Ory HW, Ishak KG, Strauss LT, Greenspan JR, Hill AP, Tyler CW Jr: Epidemiology of hepatocellular adenoma. The role of oral contraceptive use. JAMA 1979;242: 644-648.

2 Gibbs JF, Litwin AM, Kahlenberg MS: Contemporary management of benign liver tumors. Surg Clin North Am 2004;84:463480

-3 Bioulac-Sage P, Laumonier H, Laurent C, Zucman-Rossi J, Balabaud C: Hepatocellular adenoma: what is new in 2008. Hepatol Int 2008;2:316-321.

4 Chen YW, Jeng YM, Yeh SH, Chen PJ: p53 gene and Wnt signaling in benign neoplasms: $\beta$-catenin mutations in hepatic adenoma but not in focal nodular hyperplasia. Hepatology 2002;36:927-935.

5 Bioulac-Sage P, Rebouissou S, Thomas C, Blanc JF, Saric J, Sa CA, Rullier A, Cubel G, Couchy G, Imbeaud S, Balabaud C, ZucmanRossi J: Hepatocellular adenoma subtype classification using molecular markers and immunohistochemistry. Hepatology 2007; 46:740-748.

6 Zucman-Rossi J: Genetic alterations in hepatocellular adenomas: recent findings and new challenges. J Hepatol 2004;40:10361039.

7 Choi BY, Nguyen MH: The diagnosis and management of benign hepatic tumors. J Clin Gastroenterol 2005;39:401-412.

-8 Terkivatan T, de Wilt JH, de Man RA, van Rijn RR, Tilanus HW, IJzermans JN: Treatment of ruptured hepatocellular adenoma. Br J Surg 2001;88:207-209.

-9 Ault GT, Wren SM, Ralls PW, Reynolds TB, Stain SC: Selective management of hepatic adenomas. Am Surg 1996;62:825-829.

-10 Edmondson HA, Reynolds TB, Henderson B, Benton B: Regression of liver cell adenomas associated with oral contraceptives. Ann Intern Med 1977;86:180-182.

$\checkmark 11$ Ramseur WL, Cooper MR: Asymptomatic liver cell adenomas. Another case of resolution after discontinuation of oral contraceptive use. JAMA 1978;239:1647-1648.
12 Steinbrecher UP, Lisbona R, Huang SN, Mishkin S: Complete regression of hepatocellular adenoma after withdrawal of oral contraceptives. Dig Dis Sci 1981;26:10451050.

13 Parker P, Burr I, Slonim A, Ghishan FK, Greene H: Regression of hepatic adenomas in type Ia glycogen storage disease with dietary therapy. Gastroenterology 1981;81 534-536.

14 Iijima H, Moriwaki Y, Yamamoto T, Takahashi S, Nishigami T, Hada T: Spontaneous regression of hepatic adenoma in a patient with glycogen storage disease type I after hemodialysis: ultrasonographic and CT findings. Intern Med 2001;40:891-895.

15 Deneve JL, Pawlik TM, Cunningham S, Clary B, Reddy S, Scoggins CR, Martin RC, D’Angelica M, Staley CA, Choti MA, Jarnagin WR, Schulick RD, Kooby DA: Liver cell adenoma: a multicenter analysis of risk factors for rupture and malignancy. Ann Surg Oncol 2009;16:640-648.

16 Dokmak S, Paradis V, Vilgrain V, Sauvanet A, Farges O, Valla D, Bedossa P, Belghiti J: A single-center surgical experience of $122 \mathrm{pa}$ tients with single and multiple hepatocellular adenomas. Gastroenterology 2009;137: 1698-1705.

17 Cho SW, Marsh JW, Steel J, Holloway SE, Heckman JT, Ochoa ER, Geller DA, Gamblin TC: Surgical management of hepatocellular adenoma: take it or leave it? Ann Surg Oncol 2008;15:2795-2803.

18 Van der Windt DJ, Kok NF, Hussain SM, Zondervan PE, Alwayn IP, de Man RA, Ijzermans JN: Case-orientated approach to the management of hepatocellular adenoma. $\mathrm{Br}$ J Surg 2006;93:1495-1502.

19 Erdogan D, van Delden OM, Busch OR, Gouma DJ, van Gulik TM: Selective transcatheter arterial embolization for treatment of bleeding complications or reduction of tumor mass of hepatocellular adenomas. Cardiovasc Intervent Radiol 2007;30:1252-1258.
20 Stoot JH, van der Linden E, Terpstra OT, Schaapherder AF: Life-saving therapy for haemorrhaging liver adenomas using selective arterial embolization. Br J Surg 2007;94: 1249-1253.

21 Shortell CK, Schwartz SI: Hepatic adenoma and focal nodular hyperplasia. Surg Gynecol Obstet 1991;173:426-431.

22 Mueller J, Keeffe EB, Esquivel CO: Liver transplantation for treatment of giant hepatocellular adenomas. Liver Transpl Surg 1995;2:99-102.

23 Santambrogio R, Marconi AM, Ceretti AP, Costa M, Rossi G, Opocher E: Liver transplantation for spontaneous intrapartum rupture of a hepatic adenoma. Obstet Gynecol 2009;113:508-510.

24 Rhim H, Lim HK, Kim YS, Choi D: Percutaneous radiofrequency ablation of hepatocellular adenoma: initial experience in 10 patients. J Gastroenterol Hepatol 2008; 23:e422-e427.

-25 Toso C, Majno P, Andres A, Rubbia-Brandt L, Berney T, Buhler L, Morel P, Mentha G: Management of hepatocellular adenoma: solitary-uncomplicated, multiple and ruptured tumors. World J Gastroenterol 2005; 11:5691-5695.

26 Terkivatan T, de Wilt JH, de Man RA, Ijzermans JN: Management of hepatocellular adenoma during pregnancy. Liver 2000;20: 186-187.

27 Stoot JH, van der Linden E, Terpstra OT, Schaapherder AF: Life-threatening hemorrhage from adenomas in the liver during pregnancy. Dig Surg 2006;23:155.

28 Erdogan D, Busch OR, van Delden OM, Ten Kate FJ, Gouma DJ, van Gulik TM: Management of spontaneous haemorrhage and rupture of hepatocellular adenomas. A singlecentre experience. Liver Int 2006;26: 433-438.

29 Huurman VA, Stoot JH, van der Linden E, Terpstra OT, Schaapherder AF: Necrosis of a large hepatic tumor after hemorrhage and subsequent selective arterial embolization. World J Gastroenterol 2006;12:6059-6061. 